\title{
A TANÁRKÉPZŐ INTÉZET SZEREPÉNEK ALAKULÁSA A MAGYARORSZÁGI TANÁRKÉPZÉS TÖRTÉNETÉBEN
}

\section{PUKÁNSZKY BÉLA}

\author{
a Szegedi Tudományegyetem \\ egyetemi tanára \\ bela@pukanszky.hu
}

\begin{abstract}
A 2011. évi felsöoktatási törvényben nevesitett „tanárképzö központ” a magyar középiskolai tanárképzés történetében nem új. Funkcióját tekintve elözményének tekinthetö a magyar egyetemeken a 19. század végén létesitett „,tanárképzö intézet”. Ez az intézménytípus az egyetemi városokban létesült: Budapesten, majd később Kolozsváron, Szegeden, Pécsett és Debrecenben. Az volt a feladata, hogy a középiskola gyakorlatias igényeit szem elött tartva, folyamatos érdekérvényesitö diskurzust folytasson a tanitás szabadságának humboldti eszméjére hivatkozó tudományegyetemi karokkal. A budapesti és a vidéki tanárképzö intézetek az 1924. évi tanárképzési törvény jóvoltából erös legitimációra tettek szert, amelynek nyomán definiált jogositványaik birtokában már jelentős sikereket értek el a tanárképzés komponenseinek összehangolása terén.
\end{abstract}

A nemzeti felsőoktatásról szóló 2011. évi CCIV. törvény a tanárképzés reformjával összefüggésben egy új szervezeti egységet ${ }^{1}$ ír elő az állami felsőoktatási intézményekben. A 103. § első bekezdésében ,,tanárképzö központ” létrehozását rendeli el azokban a felsőoktatási intézményekben, ahol a középiskolai tanárképzés legalább két szakon folyik.

A törvényszöveg kijelöli a központ elvi síkon megfogalmazott fö feladatköreit. Eszerint ennek a szervezeti egységnek biztosítania kell ,a tanárképzés szakmai, tartalmi, szervezeti és tudományos feladatainak összehangolását, valamint az elméleti és gyakorlati képzés szervezését" az intézményben (2011. évi CCIV. törvény a nemzeti felsőoktatásról. 103. § 1. bekezdés). A következő bekezdésben a tanárképző központ feladatainak részletezésére is kitértek a törvényalkotók: „A tanárképző központ koordinálja különösen a hallgatói meghallgatást, kiválasztást, felvételt, átvételt, a kreditelismerés, a pedagógiai szakképzés, a záróvizsga letételének folya-

\footnotetext{
${ }^{1}$ A 2005. évi felsőoktatási törvény a törvényalkotói szándékot tekintve előzmények tekinthető, de a szövegezés csak az intézményi egységes szabályozás elvi elöírására korlátozódott. A több karon tanárképzést folytató intézményekre bízta, hogy egy szervezeti egység vagy egy testület létesül-e a pedagógusképzés összehangolására. (A fogalomhasználat kissé megtévesztő, ugyanis a „tanárképzés része a pedagógusképzés tágabb fogalmának.) 2005. évi CXXXIX. törvény a felsőoktatásról. 145. § 5. bekezdés.
} 
matát, és szervezi, ellenőrzi, valamint értékeli az iskolai gyakorlatot. Nyomon követi a hallgatói előremenetelt, pályakövetést végez." (2011. évi CCIV. törvény a nemzeti felsőoktatásról 103. § 2. bekezdés.) A központra vonatkozó két bekezdés közül az első egy elvi síkú feladatleírás, az utóbbi pedig - olvasatunk szerint - az előzőből emel ki és tesz hangsúlyossá konkrét feladatokat, amelyek elsősorban a képzés folyamatának szervezésére vonatkoznak.

A tanárképző központ mint felsőoktatási intézményekben létrehozott szervezeti egység nem teljesen új, ha a magyar középiskolai tanárképzés másfél évszázados történetére tekintünk vissza. Funkcióját és müködésének tartalmát tekintve több ponton előzményének tekinthető a magyar egyetemeken a 19. század végén létesített tanárképző intézet.

A következőkben ennek a történeti elöképnek, a tanárképző intézetnek kialakulásának és fejlődésének történetét tekintjük át. Arra a kérdésre keresünk választ, hogy vajon betöltötte-e ez a sajátos intézmény a létrehozók szándékai szerint meghatározott feladatait abban a konkrét történeti korban és felsőoktatási kultúrában, amelyben létezett. $^{2}$

\section{A középiskolai tanárképzés szervezeti kereteinek kialakulása}

\section{Változó középiskolák, új képesitő vizsga}

A középiskolák döntő többségének felekezeti fenntartása miatt Magyarországon a gimnáziumi tanárok képzése a 19. század közepéig az egyházak hatáskörébe tartozott, tartalmát és szervezeti kereteit a felekezetek határozták meg. A pesti egyetem bölcsésztudományi tanszékén - a bécsi egyetem mintájára - már 1814-től kezdődően rendszeresen tartottak neveléstudományi tárgyú előadásokat, ezek hallgatása viszont hosszú ideig nem volt előfeltétele a középiskolai tanári pályának (Mészáros, 1980). Ezek a választható tantárgyként felvehető pedagógiaelméleti stúdiumok jórészt a lelkipásztorok feladataival foglalkoztak és a korabeli nevelés és oktatás kérdéseit taglalták (Németh, 2012, 33. o.).

Alapvető változást hozott ezen a téren az ausztriai középiskolák szervezetét és képzési tartalmát újraalkotó reform. Ezt az erőteljes modernizációs törekvést tükrözte Leo Thun osztrák közoktatásügyi miniszter rendelete, amelyet 1849 őszén hagyott jóvá a császár. Az Entwurf ${ }^{3}$ hatályát 1850-ben Magyarországra is kiterjesztették. A rendelet a korábbi hatosztályos humán gimnázium évfolyamainak számát

\footnotetext{
${ }^{2}$ Az egykori tanárképző intézet története inspirációs hatásként megfontolandó lehet a jelen számára is, amikor az egyes felsőoktatási intézményekben napirenden van a tanárképző központ létesítése, konkrét feladatainak definiálása. Mindazonáltal figyelembe kell vennünk azt is, hogy ez a szervezeti egység a maitól eltérő felsőoktatási feltételek és körülmények között funkcionált.

${ }^{3}$ A rendelet teljes címe: ,Entwurf der Organisation der Gymnasien und Realschulen in Oesterreich”, azaz: Az ausztriai gimnáziumok és reáliskolák szervezeti terve.
} 
nyolcra emelte, a középiskolai tananyag tartalmában a humán és a reál ismeretek egyensúlyára törekedett. A tanulmányok végére érettségi vizsgát illesztett, amely a felsőbb tanulmányokra, illetve bizonyos köztisztviselői állások betöltésére jogosított. Ugyanez a reform hozta létre az előbb hat, majd később nyolcosztályos reáliskolát, amely a felsőfokú müszaki-technikai tanulmányokra készített elő. ${ }^{4}$

A Magyarországra is kiterjesztett német-osztrák tanügyi reform a középiskolai tanárképzés terén is alapvető változásokat hozott. Különös, de először az intézményesen még nem létező képzés „kimenetét” szabályozták: kötelezővé tették a független bizottság előtt abszolválandó képesitő vizsgát a tanárságra készülők számára. Ausztriában előbb ideiglenes jelleggel, majd 1856-tól törvényben meghatározott keretek között került sor a középiskolákba kinevezendő tanárok képesítő vizsgájára. Tanárvizsgáló bizottságot Magyarországon csak az 1862/63. tanévben állítottak fel, addig csak néhány külföldi városban - elsősorban Bécsben - vizsgázhattak a hazai jelöltek is (Felkai, 1983). A tanári vizsga elöfeltétele a sikeres érettségi és legalább három év egyetemi tanulmány megléte volt. Három tantárgycsoportból kellett vizsgázni: 1. klasszika-filológia, 2. történelem és földrajz, 3. matematika és természettudomány. A vizsgának négy összetevője volt: 1. házi dolgozat, 2. írásbeli vizsga, 3. szóbeli vizsga, 4. próbatanítás. Ez a rendszer a század végéig érvényben maradt, bár a próbatanítást 1884-ben megszüntették (Németh, 2012, 60. o.).

\section{A humboldti egyetem-eszmény}

Az újkori közép-európai egyetem legjelentősebb archetípusa a 18. század végétől kezdve lezajló filozófiai diskurzus eredményeként létrejövő neohumanista müveltségeszményre épült, amelynek legföbb képviselője Wilhelm von Humboldt volt. Felfogása szerint az egyetemen feladata a tudományos kutatás és a tudomány tanítása, amely utóbbinak az emberi tartalmak kiteljesítése a „Bildung” (jellemformáló müvelődés) révén kell végbemennie. Az ilyen, klasszikus közép-európai egyetem működésének alapvető feltétele a szabadság. Nem türheti az állam gyámkodását és ellenőrző-befolyásoló szerepét sem a tudományos kutatásban, sem pedig a tanításban. A kutatva-tanítás szabadságának humboldti eszménye nehezen egyeztethető össze a közéleti hivatásra felkészítő szakemberképző szereppel. ${ }^{5}$ Az egyetem falai között elsősorban a tanárok és a hallgatók elmélyült közös munkáján alapuló tudósképzés folyik, minden egyéb funkció járulékos.

Magyarországon az 1848. évi XIX. törvénycikk deklarálta az egyetemi tanszabadságot. Hatására megszüntek a korábbi kötöttségek: a hallgatók maguk határoz-

\footnotetext{
${ }^{4}$ Az 1851/52-es tanév a pesti egyetem életében is döntő fordulatot hozott. A Leo Thun-féle reform hatására ettől kezdve a bölcsészkar kiemelkedett addigi, a többi karra előkészítő „propedeutikus” szerepköréböl, és a másik három egyetemi fakultással egyenrangú karrá vált.

5 A humboldti eszménnyel párhuzamosan, azt ellenpontozva létrejövő francia egyetem-koncepció a szakképző (,szakiskola”) funkciót hangsúlyozza.
} 
hatták meg a hallgatott előadások sorrendjét. ${ }^{6}$ Az új gyakorlat azonban sokszor vezetett az oktatás és a tanulás parttalan szabadságához. A professzorokat senki sem kötelezte előadásaik témájának célszerủ szempontok szerint való alakítására, a hallgatók pedig önkényesen válogathattak az előadások között. A tanítás és tanulás szabadságának értelmezéséről, illetve ennek a szabadságnak a célszerúen szervezett szakmai képzés érdekében történő korlátozásáról szenvedélyes hangvételü és hosszadalmas - a századfordulón is átívelö - vita vette kezdetét.

A középiskolai tanárképzés Magyarországon az egyetemen intézményesedett, ezért a vita a fokozatosan kialakuló és szakmává váló tanárképzés tartalmát és szervezeti kereteit is érintette. A diszkusszió főbb elemeire a későbbiekben térünk vissza.

\section{A középiskolai tanárképzés ,pillérei”}

A fokozatosan kibontakozó professzionalizációs folyamat során a magyar középiskolai tanárképzés rendszere a következő négy - egymást kiegészítő - „pilléren” épült fel: 1. egyetemi előadások a szaktudomány témaköreiből; 2. egyetemi szemináriumok, kollégiumok, illetve gyakorlatok; 3. középiskolai tanárképző intézet; 4. gyakorló gimnázium. A ,pillérek” tanárképzésben betöltött funkciójának a fejlődéstörténetét a következőkben tekintjük át.

\section{Egyetemi előadások a szaktudomány átfogó vagy szükebb témaköreiböl}

A tizenkilencedik század végére a szabad előadás müfaja kiszorította a korábban gyakran alkalmazott szövegmagyarázatokat és a diktálást. Az uralkodóvá vált felfogás szerint az előadás alkalmat ad a hallgatóságnak, hogy „bepillantson a tudomány mühelyébe, a tudós búvárlatba" (Kármán, 1895, 77. o.). A tudomány müvelése mellett folytatott rendszeres egyetemi oktatás ekkorra már a kutató tudósok nagy részének belülről fakadó szükséglete lett: „Az a tudós, aki soha nem adott elö, vagy csak hosszabb ideig szünetelt tanári tisztében, tapasztalta, hogy büntetlenül nem hagyhatni abba a tanítást évek során át. A nyilvános előadás arra kötelez, hogy a tudománynak, mellyel foglalkozunk, sorban fölkaroljuk minden részletét különös vonatkozásaiban, valamint más tudományokkal kapcsolatban." (Pasteurt idézi Kármán, 1895, 77. o.) Figyelemre méltó, hogy a kortársak a jó előadás ismérveként nem csak a minden ízükben kimunkált tudományos rendszerek bemutatását tartották számon, hanem elismerően nyilatkoztak az olyan előadóról is, aki „öszintén feltárja hallgatósága előtt kétségeit, számot ad: leküzdésökben a tudomány készlete mennyiben nyújthatott segítséget, hol szorult az akadályokkal szemben új eszközök

\footnotetext{
${ }^{6}$ Azt megelőzően az egyetem szoros állami felügyelet alatt állt. II. József intenciója érvényesült, miszerint ,az ifjaknak az egyetemen ne tanítsanak olyasmit, amit ők vagy igen ritkán, vagy talán éppenséggel nem értékesíthetnek az állam javára, mivelhogy az egyetemek lényeges tudományai csakis állami hivatalnokok képzésére valók". (Idézi: Schneller, 1900, 154. o.)
} 
szerzésére, elütő eljárásmódok kieszelésére: e vallomásszerủ nyíltságában, személyiségének varázsával nem versenyezhet semmi más módja a tanításnak..." (Kármán, 1895, 77-78. o.)

A humboldti neohumanista egyetemeszmény megvalósulása a német, az osztrák és a korabeli magyar egyetemek ${ }^{7}$ gyakorlatában felemás eredményeket hozott. Mint arra már korábban utaltunk, a korabeli kritikák föleg a professzorok parttalan tanítási szabadságát és előadásaik öncélú elmélet-központúságát vették célba. Kármán Mór például így ír erről: „A philosophiai kar, mely az alapvetés munkáját se tudta eddig egyetlen egy szakban sem czészerüen szervezni, következetesen, az egész tanfolyam végéig sem törődött növendékeinek későbbi hivatásával. Pedig a közmüvelődés érdeke [...] erősen megköveteli a tanítás mennél gyakorlatibbá tételét. [...] De a tanárképzés szempontjából a philosophiai kar munkássága még elméleti irányban is oly pótlást követel, mely nélkül eddig tudósképző feladatát is csak fogyatékosan teljesíthette”. (Kármán, 1895, 142. o.) A hazai bölcsészkari oktatás rendszabálya például csak a heti tíz (majd a század utolsó évtizedétől heti 20) óra felvételének igazolását várta el. Az előadások körének meghatározását a tanszabadság elvével ellentétesnek tartották (Ladányi, 2008, 28. o.).

Az egyre nyilvánvalóbbá váló anomáliáknak az orvoslására szerveződtek előbb az egyetemi szemináriumok, illetve később, a század második felében - egyebek között - e célból jött létre a pesti egyetem tanárképző intézete.

\section{Egyetemi szemináriumok, kollégiumok, gyakorlatok}

Már az 1830-as évektől kezdve felmerült az igény Európa nagy egyetemein arra, hogy az egyetemi tanárok elméleti előadásait gyakorlatokkal egészítsék ki.

A skót és az angol egyetemeken ennek következtében alakult ki az elöadás (lecture) és a tutori gyakorlat (tuition) kettős rendszere. Szükségesnek látták, hogy az egyoldalú tanárközpontú ismeretközlést, amely ha mégoly lelkesítő és magával ragadó is, mégis csak a hallgatóság figyelmére és tudásbefogadására alapoz, kiegészítsék a tanulóknak a tanár által irányított egyéni munkájára épülő gyakorlatokkal, amely az öntevékenységet, az önálló elemzéseket, a tudás alkalmazását hivatott fejleszteni. Egy korabeli angol szerző a következő szavakkal indokolta a tudomány és a gyakorlat összekapcsolásának szükségességét: „Az egyetem a professor számára való, a collegium a tutor számára: az egyetemé a bölcseleti fejtegetés, beszédes előadás vagy alapos meghányás; a collegiumé az egyszerü, dialogikus oktatás. [...] Fiatal embernek nem könnyü dolog, hogy megbizonyosodjék benne, teljesen megértette-e azt a mit tanárától hallott; gondos kérdezés meg felelés, és minden látszatot kerülő vizsgálat, vajjon képes-e ismereteit kellően kifejezni és számot adni róluk,

\footnotetext{
${ }^{7}$ A 19. században Magyarország területén Pesten és Kolozsváron működött egyetem. (Az előbbi a nagyszombati egyetem jogutódja, 1784-ben Budáról telepítették Pestre, az utóbbit pedig 1872-ben alapították.)
} 
lesz még szükséges, hogy jeles tanárait igaz haszonnal hallgassa; mindezt tutora adja meg neki a collegiumban.” (Newmant idézi Kármán, 1895, 85. o.)

A professzor és a hallgató közös munkájának eszménye a korabeli francia felsöoktatásban hangsúlyos elvárásként jelent meg: „A felsőbb oktatásnak - írta a Sorbonne egy tanára - tulajdonkép, par excellence a családias társalgás az alakja, a conference a szó igazi értelmében. Nem ismeretekkel tömött elmék képzendők, hanem a kik képesek kutatni és önmaguk gondolkozni [...] Ily oktatás formája a lelkes beszélgetés, egy tudósnak tevékeny együttes munkálkodása tanítványaival laboratotiumában". (Mariont idézi Kármán, 1895, 95. o.) A francia egyetemeken ekkor már a tudósképzés mellett a tanárképzés gyakorlati szempontjait is hangsúlyozottan figyelembe vették. ${ }^{8}$

A német egyetemek fejlődése más úton haladt. Szemináriumokat már a 18. században létrehoztak, melyek feladata eredetileg - a tudósképzés mellett - a tanári pályához szükséges szaktudományos ismeretek nyújtása volt. Ez a szempont azonban a 19. század elejére háttérbe szorult. A gyakorlati szemináriumok létesítését az egyetemeket felügyelö állami szervek is szorgalmazták. Poroszországban maga a kultuszkormányzat figyelmeztette az egyetemi professzorokat abbéli kötelességükre, hogy az előadások mellett alkalmazzanak olyan módszereket is, mint például a tanár és a diák dialógusára épülő megbeszélés, a beszélgetés és a vizsgálat. Ez a felülről induló kezdeményezés kezdetben erős visszatetszést váltott ki a tanárság körében azokon a német egyetemeken, ahol elsősorban a tudomány müvelését és nem a gyakorlati életre való felkészítést tartották a fő célnak. Így alakulhatott ki az a helyzet a század második felére, hogy a német egyetemi szemináriumokba nem azok a hallgatók kerültek be, akik személyes tanári segítségnyújtásra szorultak az anyag feldolgozásában, hanem a kiváló képességúek gyakorlati tudósképzésének - és a középiskolai tanárságra való szaktudományos felkészítésének - a mühelyei alakultak ki itt.

A német mintát követve a pesti egyetemen már a század ötvenes éveinek elején szerveztek olyan szemináriumokat, ahol a szaktudományos kutatómunka módszereinek gyakorlása mellett a tanárképzés szempontjait is érvényesíteni kívánták. E kettős cél összeegyeztetése azonban itt sem járt sikerrel, és „tanári ügyesség” megszerzése háttérbe szorult a „tudós búvárlatba” való bevezetéssel szemben.

Más felfogást képviselt az 1872-ben alapított kolozsvári egyetem pedagógia professzora, Schneller István. „Az egyetemi tanulmányozás feladata” címü, a századfordulón közzétett tanulmányában behatóan foglalkozott az egyetemi szemináriumok kérdésével. Véleménye szerint a professzor, aki egész életét a tudomány müvelésére és tanítására szenteli, nem elégedhet meg előadások tartásával. Annak érdekében, hogy hallgatóiban a tudomány szeretetét felkeltse és ápolja, „szaksze-

\footnotetext{
${ }^{8}$ A párizsi Sorbonne természettudományi kara például már 1837-ben kifejezte szándékát arra, hogy az egzakt tudományos előadások mellett célja a hallgatóság felkészítése a tanári pályán megkövetelt vizsgákra. Az École Normale Supérieure feladata pedig kifejezetten a tanári szakképzettség nyújtása volt.
} 
mináriumokat" kell szerveznie. Gyüjtse maga köré a lelkes hallgatókat, s vezesse be őket a tudományos önmunkásság módszereibe. A szakszemináriumok azonban kizárólag a tudományos képzés szempontjait tarthatják szem előtt, s nem kapcsolhatók össze a gyakorlati életre, a tanári pályára való gyakorlati-módszertani felkészítéssel (Schneller, 1900, 124-174. o.).

\section{Középiskolai tanárképzö intézet}

Eötvös József vallás- és közoktatásügyi miniszter már 1848-ban megoldást keresett a középiskolai tanárképzés problémáira. „A magyar egyetem alapszabályai” címmel tervezetet készített, amelyben megfogalmazta, hogy ,a tudós közép- és polgártanodák leendő tanárainak kiképzésére külön philologico-historai és mér- és természettani képezdék fognak az egyetem bölcsészkara mellett felállíttatni." (Idézi Felkai, 1983, 285. o.) A tervezetnek az országgyúlés elé való terjesztését a szabadságharc kitörése akadályozta meg.

Eötvös második kultuszminisztersége idején a tervezet már valóra vált, és 1870. május 3-án jóváhagyta a Középtanodai Tanárképző (későbbi nevén Középiskolai Tanárképzö Intézet) szervezeti szabályzatát. A pesti egyetemen felállított „képezde” célja eszerint az, hogy „,azon egyetemi hallgatókat, s egyéb tanárjelölteket, kik középtanodai tanárságra készülnek, a szükséges előismeretek igazolása után, választott szaktanulmányukban és annak módszertani kezelésében alaposan kiképezni, s öket tudományos öntevékenységre ösztönözve arra képesíteni, hogy tanári hivatásuknak mind tudományos készültségük, mind a tudományoknak módszertanilag helyes kezelése által minél tökéletesebben megfelelhessenek”. (Közli: Kármán, 1895, 50-62. o.)

A tanárképző intézet feladata volt tehát, hogy a középiskolai tanárságra készülő hallgatókat egyidejűleg ösztönözze a szaktudományos búvárkodásra, és a szaktárgyak tanításával kapcsolatos módszertani ismeretek elsajátítására. Az első években a tanárképző intézet keretei között öt szakosztály müködött, nevezetesen az a) óklasszikai, nyelvészeti és irodalmi, a b) történelmi-földrajzi, a c) mennyiség- és természettani, a d) természetrajzi és az e) pedagógiai. Ez utóbbit, a vele együtt létesített gyakorló gimnáziummal együtt 1872-ben hozták létre. Szervezésében és müködési rendjének meghatározásában kulcsfontosságú szerepet játszott Kármán Mór, az tanárképzési reformmunkálatok kiemelkedő pedagógus egyénisége (Közli: Kármán, 1895, 60-62. o.).

A szabályzat szerint a pedagógiai szakosztály keretei között már nem a nevelés-oktatás általános alapelveivel ismerkedhettek meg a jelöltek - ezeket ugyanis a pedagógia egyetemi tanára előadásaiban már tárgyalta, $\mathrm{s}$ a hallgatók szemináriumi munkával már feldolgozták -, hanem a „,gymnasialis paedagogia” speciális kérdéseit tanulmányozták. Így került sor a „középtanodák ismeretkörének paedagogiai szempontból való feldolgozására, s az abbeli iskolai életnek a jó nevelés, a helyes 
fegyelem követelményeinek megfelelő megszervezésére". (Közli: Kármán, 1895, 60. o.) A szakosztály célja tehát kifejezetten a pedagógiai képességek és „ügyességek" elsajátítása volt. Ennek érdekében tartották a fentebb jelzett tematikájú, az oktatás gyakorlati kérdéseit tárgyaló előadásokat is.

A hivatalba lépő új kultuszminiszter, Trefort Ágoston 1873 őszén átszervezte a tanárképző intézetet. Az új szabályzat két ponton tért el az eredeti, Eötvös-féle elvektől: 1. Egyesítette a gimnáziumi és a reáliskolai tanárképzés addig két különálló intézetét. 2. Ezt az összevont intézetet az egyetemi tanács hatásköréből a bölcsészettudományi kar $^{9}$ tanácsa mellé rendelte (Kiss, 1991, 6. o.). Ennek következtében a tanárképző intézet a bölcsészkar mellett müködő, de attól szervezetileg független intézmény lett, amely közvetlenül a minisztérium alá tartozott.

A szakosztályok száma az új rendszerben háromra (nyelvészeti-történelmi, mennyiségtan-természettudományi és nevelés-oktatástani) csökkent. A szabályzat elöírta, hogy minden hallgatónak legalább két középiskolai tantárgy oktatására kell képesítést szereznie. A legjelentősebb lépés a tanárképzés tantervének a bevezetése volt: a statútum nyomatékosan hangsúlyozta, hogy a tanárképzőben az oktatás „,rendes, kötelezett tanterv alapján történjen.” Ennek kidolgozásakor „alapelvül szolgáljon az, hogy kezdetben az elméleti és gyakorlati oktatás középpontját a szorosan vett szaktárgy oly terjedelmű és modorú kezelése képezze mint a milyen a középtanoda közvetlen érdekeinek és igényeinek leginkább megfelel..." (Közli: Kármán, 1895, 62-64. o.). A Trefort-féle szabályzat intenciója jó példája annak, ahogyan az állam egy konkrét cél, a korszerü tanárképzés igényeinek való megfelelés érdekében korlátozni kívánta az egyetemi karokon folyó oktatás addigi, szinte parttalan szabadságát.

A tanárképző intézet vezetése ugyanis ettől kezdve a tanterv alapján egységesen előírta a jelöltek számára, hogy az egyetemi és mủegyetemi karokon mely szaktudományos előadásokat hallgassák és mely szemináriumokon vegyenek részt. Ezekkel párhuzamosan az intézetben a tanári pályához szükségesnek vélt pedagógiai szempontú előadásokat és gyakorlatokat szerveztek. Az ezeket előadó, illetve vezető oktatók továbbra is az egyetemi tanárok köréből kerültek ki. ${ }^{10}$

Kármán Mór a tanárképzés fejlesztésének kérdéseit taglalva hangsúlyozta, hogy a bölcsészeti karnak jogai és kötelességei vannak a tanárképzés terén: „A tanárképzés csak az egyetemet illeti meg: egyetemünk bölcsészet karának a kötelessége,

\footnotetext{
${ }^{9}$ Önálló természettudományi kar a pesti egyetemen akkor még nem létezett. A nem orvosi jellegü természettudományi tanszékek is a bölcsészeti karon müködtek.

${ }^{10}$ Kármán Mór már 1875-ben síkra szállt a tanárképző intézet saját tanári karának felállításáért: ,,... képezde sajátképi feladatának, mely a tanulmányok gyakorlati elsajátítására, a kellő jártasság s ügyesség megszerzésére, s föleg leendő tanáraink általános müveltségének öregbítésére vonatkozik, sem felelhet meg kellő mértékben mindaddig, míg e czélra egyedül az egyetem s mủegyetem illető szaktanárai csak mellékesen vétetnek igénybe és a képezdének sajátos föladata szerint szervezett, külön önáll tanártestülete nincs.” (Kármán, 1875. In: Kármán, 1895, 2. o.)
} 
hogy rendszeres tanfolyamait a tanárképzés szükségleteinek megfelelően szervezze.” (Kármán, 1895, 147. o.). A filozófiai kar tehát nem húzódhat az öncélú tudósképzés sáncai mögé, ki kell vennie részét a nemzet közmüvelődésének, oktatásügyének szolgálatából. Ez a követelés a pesti egyetem bölcsészkarának határozott elutasításába ütközött. A „tanszabadság versus tervszerüség” vita most már a tanárképzés területére is kiterjedt. Kialakult egy - azóta is tartó - országos méretüvé terebélyesedő diszkusszió a tanárképzés célszerünek vélt tartalmáról, a szaktudományok, a pedagógiai-módszertani ismeretek és a gyakorlatok egymáshoz viszonyított kívánatos arányáról. A képzésben részt vevő intézmények kapcsolata továbbra is problematikus maradt, ezért a vita kiterjedt a tanárképző intézet kompetenciájára, hatáskörére és a befolyásolás vagy kooperáció kérdésére is. A legnagyobb gondot a tanárképző intézeti tagság „fakultatív jellege” okozta, ez ugyanis a tanárjelöltek számára az 1924. évi XXVII. törvénycikk életbe lépéséig nem volt kötelezö.

A fentebb már említett diszkusszió egyik érdekes fejleménye volt az a felterjesztés, amelyet a pesti egyetem bölcsészettudományi kara 1878. március 21-én nyújtott be Trefort Ágoston kultuszminiszternek. A bölcsészkar vezetése ebben hevesen támadta a tanárképző intézetet. Kiállt amellett, hogy a középiskolai tanárképzés kizárólag az egyetemi kar ügye legyen. Kifogásolta, hogy az egységesen írja elő a tanárjelölt hallgatók számára a célszerünek vélt egyetemi előadásokat és szemináriumokat, és nem figyel a tanárjelöltek egyéni tudására, felkészültségére. Ezek a minden jelölt számára kötelező tanrendek és órarendek túlterheléshez vezetnek, lehetetlenné teszik a hallgató „önálló gondolkodásának” és „,egyéni hajlamainak” a fejlődését. A tanárképzés szervezésében egy formális, „élet- és szellemtelen külső mechanismus nyüge" uralkodik (Kerékgyártó, 1879. In: Kármán, 1895, 20-30. o.). A felterjesztés a „tanárképezde” megszüntetését kérte a minisztertől. Helyette a bölcsészkari szemináriumok számának növelését javasolta, a képzés időtartamának három évről négyre történő emelése mellett. Trefort a bölcsészkar indítványát véleményezésre továbbította szakmai tanácsadó és véleményező testületéhez, az Országos Közoktatási Tanácshoz. A Tanács jelentésében kitért arra, hogy a bölcsészkart múltja „nem jogosítja fel azon önérzetes állításra, hogy a tanárképzést kizárólagos tisztének” tekintse. A karon hirdetett előadások ugyanis „,a leglényegesebb tárgyakban az iskola szükségletének majdnem teljes mellőzését" mutatják (Ladányi, 2008, 22-23. o.).

\section{Gyakorló gimnázium}

Fentebb már említettük, hogy a pesti egyetemen az 1870-től müködő tanárképző intézetben - Kármán Mór koncepciója alapján - 1872-ben jött létre a nevelésoktatástani szakosztály. Ennek szabályzata a pedagógiai és módszertani előadások mellett a gyakorló iskolát is nevesítette, meghatározva annak célját, szerkezetét és irányítását: „86. §. A gyakorló iskola a gyakorlati kiképzésre szolgál, Feladata, 
hogy oly mintaszerü iskolai életnek adja képét, melyben a tanítványok erkölcsi és értelmi haladása az egész tantestület közös gondjának képezi tárgyát, és mely a tanárjelöltnek buzdító például, a tanárnak lelkesítő emlékül szolgáljon.” (Idézi: Kármán, 1895,61 o.) A gyakorló gimnázium nyilvános jelleggel ${ }^{11}$ bíró állami intézmény volt, tantervét, óra- és ügyrendjét az igazgató és a tanár kar értekezlete határozta meg, és a közoktatási miniszter hagyta jóvá. A nyolcosztályossá kiépülő iskola az 1872/73. tanévben két osztállyal (I. és III.) indult, meglehetősen nehéz anyagi körülmények között. Első igazgatója Bartal Antal klasszika-filológus professzor volt. Kármán Mór tanította a filozófiát és pedagógiát, Heinrich Gusztáv a történelmet és a földrajzot, Lutter János a természettant és a matematikát, Staub Mór a természetrajzot. A tanári kar tagja lett később Beke Manó, Csengery János, Négyesy László és Petz Gedeon is. A gyakorlóiskola sajátosan új, pedagógiai-módszertani mühely jellegének kiformálásában meghatározó szerepet játszott Kármán Mór, aki egyben a tanárképző intézet tanára, az Országos Közoktatási Tanács jegyzője és a pesti egyetem magántanára is volt. A bölcsészkar pedagógia tanszékével az iskolának nem volt formális kapcsolata.

A gyakorlóiskolában folyó tanárképzés három fő tevékenységtípusban öltött testet: 1 . hospitálás, gyakorlótanítás, megbeszélés; 2 . heti közös tanári értekezletek valamennyi tanárjelölt részvételével; 3. iskolaelméleti előadások (korabeli nevükön: teoretikumok) (Kiss, 1991, 15. o.). A gyakorlati képzés leglényegesebb része a több hétig tartó önálló tanítás volt. Erre a jelöltek csak akkor kaptak engedély, ha a hospitálások végeztével óratervekkel is tudták igazolni felkészültségüket a vezetőtanár számára. Az óratervek alapján folyó gyakorlati tanítást mindenki látogathatta. Kármán Mór kezdeményezésére a hospitálók számára látogatókönyveket nyitottak, amelyekbe bejegyezhették észrevételeiket, kritikai megjegyzéseiket. Az egykori tanárjelölt, Marczali Henrik történész professzor így emlékezett vissza az óralátogatások alapján készült véleményekre: „Mi jelöltek, ha egymásnál hospitáltunk, ritkán mulasztottuk el az alkalmat, hogy megjegyzéseinket, néha meglehetősen maró módon az erre szolgáló könyvbe ne írjuk. Ebböl aztán éles válaszok és keserü viszontválaszok keletkeztek, melyek azután a köztünk fennálló jó viszonyt alig érintették. Minthogy a legkülönbözőbb tárgyú leckéknél hospitáltunk, a próbaelőadáson megjelenni pedig kötelesség volt, a gimnázium szellemének megfelelö minden irányban megtanultunk érdeklődni." (Marczali Henrik visszaemlékezését idézi: Kiss, 1991, 15. o.) Kármán mintagimnáziumának belső élete hozzásegítette a jelölteket ahhoz, hogy kritikusan és önkritikusan gondolkodó, a középiskola minden tárgya

\footnotetext{
${ }^{11}$ Az Entwurf óta a hazai középiskolák nyilvános vagy magánjellegủek lehettek. A nyilvános jelleggel bíró gimnáziumok államilag érvényes bizonyítványokat adhatnak ki, érettségi vizsgákat tarthatnak. Nyilvánossági jogot a kultuszminiszter adhatott.
} 
iránt érdeklődő sokoldalú tanárokká válhassanak, akik nyitottak és felkészültek az új oktatási módszerek kipróbálására is. ${ }^{12}$

\section{Diskurzusok a tanárképzésről, a tanárképző intézet feladatáról}

A középiskolai tanárképzés tartalmi és szerkezeti kérdéseiről folyó viták a későbbiekben sem vesztettek intenzitásukból.

Eötvös Loránd a középiskolai tanárképző intézet létjogosultságát is megkérdőjelezte. Wlassics Gyula kultuszminiszterhez felterjesztett memorandumában 1896-ban a következő szavakkal szállt síkra a tanárok minél alaposabb tudományos képzéséért 1896-ban: „...mert födolog a tanárképzésben a tudományos képzés. A középiskolai tanár ne csak járatos legyen a maga szakmájában, hanem igazi tudományos szellemben foglalkozott légyen vele. [...] Igaz, hogy a középiskolai tanár csak a tudományok elemeit közli - mégpedig fejletlen elmékkel - de rendszerint mennél magasabban áll a maga tudományában, annál jobban tud leszállni a fejletlen elmékhez. A didaktika müvészetének is, melynek értékét nem kicsinyeljük, csak a tudományosan képzett ember tudja igazán csak a hasznát venni. E nélkül a didaktika dressurahoz vezet, s a legkitűnőbb dressura sem nevel jó tanárokat." (Közli: Kiss, 1991, 9. o.)

Arra is volt példa, hogy az egyes álláspontok az évtizedekig tartó folyamatos diszkusszió során alakultak, fejlődtek. Schneller István kolozsvári pedagógia professzor a huszadik század első évtizedének végéig egy olyan középiskolai tanárképzés vízióját vetette papírra, amelyben élesen elkülönül az elméleti és a gyakorlati képzés. Koncepciója szerint a legfontosabb elméleti tanárképzés maga az egyetemi stúdium a szaktudományos előadásokkal és a szemináriumot és könyvtárat egyesítő „dolgozóintézetekben” folyó elmélyült búvárkodással. Az egyetem elsőrendủ feladata a tudományos igazság kutatása, ennek legfontosabb eszköze a tanulmányozás minden bürokratikus kötöttségétől mentes szabadsága. „E szellembe való bevezetés, e szellemtől való áthatás a tanárképzésnek alapvető, legfontosabb része. Midőn az egyetem éppen ezt a feladatot teljesíti: az egyetem maga - a legfontosabb tanárképző." (Schneller, 1910, 175. o.) Az egyetemet ebben a munkájában vizsgákkal nem volna szabad zavarni - ezek csak megakasztják az önmunkálkodás koncentrációt igénylö folyamatát. Külön tanárképzö intézet felállitása sem helyes, mivel az hátráltatja az elmélyült kutatómunkát.

A pedagógia egyetemi tanárának nem feladata, hogy az oktatás és a nevelés mesterségének gyakorlatába bevezesse hallgatóit, a professzor koncentráljon az elméleti pedagógiai kérdések szakszerủ tárgyalására. Külön gyakorlógimnázium

\footnotetext{
${ }^{12}$ Az addig szinte kizárólagosan alkalmazott és a tananyag mechanikus átadására korlátozó közlőprelegáló módszerekkel szemben itt alkalmazták először a diákokat aktivizáló, találékonyságukra építő heurisztikus, „kitaláltató” módszert (Felkai, 1983, 270. o.).
} 
felállítására sincsen szükség - hangoztatta ekkor még Schneller István. A jelöltek gyakorlati kiképzése az egyetemtől független, kiemelkedő színvonalú középiskolákban szervezendő gyakorlati tanárképző intézményekben, az úgynevezett „,szeminárgimnáziumokban”, „középiskolai szemináriumokban” kell, hogy történjen - kiváló szaktanárok vezetésével.

Schneller Istvánnak korábban e kérdésröl kialakított véleménye még 1906-ban is változatlan maradt, amikor kinevezték a kolozsvári egyetem mellett müködő (a budapesti mintát követő) tanárképző intézet élére igazgatójává. A gyakorlati tanárképzésről alkotott felfogása a század második évtizedében viszont már gyökeresen megváltozott. 1917-ben az ő koncepciója alapján hozták létre a tanárképző intézet fennhatósága alá tartozó kolozsvári gyakorló reform-középiskolát.

A fentiekkel ellentétben Kármán Mór mindvégig egy kiegyensúlyozott, minden összetevőjét tekintve az egyetemhez kötődő koncepciót képviselt. Az Országos Középiskolai Tanáregyesület 1891. júliusi közgyülésén mondott beszédében határozottan síkra szállt amellett, hogy a középiskolai tanárok elméleti képzése a bölcsészettudományi kar feladata. Mindemellett elhatárolódott azoktól a felmerülö újabb nézetektől, amelyek a tudományos képzés szerepét lebecsülték és a tanárképzést szervezetileg le kívánták választani az egyetemtől (Ladányi, 2008, 31. o.). A tanárnak ,a müveltség és a tudományos képzés legmagasabb fokára kell törekednie, a legmagasabb képzésnek helye minden nagy tudományos szakra nézve pedig egyes egyedül az egyetem. [...] a tanár pálya sokoldalú, széles körü müveltséget követel. [...] Ily széles körü tudományos mủveltséget máshol nem szerezhetni, mint csakis az egyetemen." (Közli: Ladányi, 2008, 31. o.)

\section{A középiskolai tanárképző intézetek szerepének alakulása a húszas, harmincas években}

A magyarországi középszintü iskoláztatás történetében az 1920-as évek hoztak jelentős változásokat. Az évtized elején hivatalba lépő új kultuszminiszter, Klebelsberg Kuno intenciói alapján végrehajtott reform célja a tananyag korszerüsítése és a középiskolák rendszerének differenciálása volt. A középosztály körében addig előnyben részesített humán jellegü stúdiumok és az azok révén megszerzett egyoldalú szaktudás akkor már nem felelt meg a kor követelményeinek. A miniszter ezért erőteljesen szorgalmazta a középiskolai tananyag gyakorlatiasabbá tételét, valamint az élő idegen nyelvek oktatását. A modernizálást szolgálta az iskolarendszer differenciálása is: a nyolcosztályos humán gimnázium és a reáliskola közé az új típusú reálgimnáziumot illesztették be. Ez az iskolafajta a tantárgyak közé a humán gimnáziumból átvette a latint és a németet (ez utóbbi mindhárom iskolatípusban kötelező volt). Melléjük felvett még egy modern nyelvet (az angolt, a franciát vagy az olaszt). A humán gimnáziumban a modern nyelvek helyett görögöt tanítottak, a reáliskolából hiányzott a latin és a görög. A matematika és a természettudomá- 
nyos tárgyak oktatására fordított idő viszont a reáliskolában volt a legmagasabb. Mindhárom középiskola-típusban azonos súllyal szerepeltek az úgynevezett nemzeti tárgyak (magyar nyelv és irodalom, történelem). Új fejlemény volt az „egységes jogosítás" elvének érvényesítése is, amelynek értelmében mindhárom középiskola-típus érettségi vizsgája jogosított valamennyi felsőoktatási intézménybe történő felvételre. Az új középiskola-rendszert az 1924. évi XI. törvény szentesítette.

A középiskolai tanárok képzéséről és képesítéséről szóló új törvénytervezet előkészítési munkálatai már az évtized elején elkezdődtek. Szakmai fórumokon időközben ismét új fejezet kezdődött az évtizedek óta folyó „tanárképzés-vitában”. Az évtized elején megerősödtek azok a törekvések, amelyek a tudós- és a tanárképzés szétválasztására törekedtek. Az előzőt a továbbra is érintetlen autonómiával és tanítási szabadsággal rendelkező egyetemi karokra, az utóbbit pedig a tanárképző intézetben alkalmazott középiskolai tanárokra bízták volna. E törekvés térhódításának eredményeként a tanárképző intézetek felügyeletét Haller István kultuszminiszter a középiskolai ügyosztály feladatkörébe utalta át, ahonnan azt csak az 1931 augusztusában hivatalba lépő Klebelsberg Kuno helyezte vissza az egyetemi ügyosztály feladatkörébe (Ladányi, 2008, 52. o.).

A képzés elemeit szétválasztó, ,prakticista” paradigmával való határozott szembefordulás látványos mozzanata volt az a megnyitó előadás, amelyet Fináczy Ernő, a budapesti egyetem pedagógia professzora, a Magyar Pedagógiai Társaság elnöke tartott a 1922. február 18-án megrendezett közgyülésen. Fináczy meggyőző erejü, kritikus leírását adta az egyetemi tudósképzésnek, amely a tanárképzés szempontjait továbbra sem veszi figyelembe. Az egyetemet végzett jelölt ,...nem viszi magával a szakmájához tartozó középiskolai anyag teljes tudományos készletét, s amit ebböl az anyagból egyetemi tanulmányainak folyamata alatt hallott és feldolgozott, azt nem úgy hallotta és nem úgy dogozta fel, hogy középiskolai teendőivel szorosabb vonatkozásba hozhassa. A tudománynak csak egyes területeivel ismerkedett meg, s ezeken is inkább kutató, mint tanító célzattal mozgott. Nem történt gondoskodás arról, hogy szerves egymásutánban és egymáson felépülő fokozatokban vegye birtokba szaktudományának anyagát. Tudományos ismereteiben hézagok maradtak, melyeknek tanári müködése vallja kárát. Nem kapott áttekintést szaktudománya összes részein, s így nincsen egységes szempontja, melynek mértékével élhessen, mikor a tudomány nagy anyagából kell merítenie az iskola számára". (Fináczy, 1922, idézi Simon, 1959, 361. o.) Fináczy a tanárképzés szempontjai szerint elégtelen egyetemi tudósképzés heves bírálata után kiállt a képzés egységének megtartása mellett: „A tudósképzésnek és a tanárképzésnek éles elkülönítése óhatatlanul leszállítaná középiskolai tanárságunk tudományos készültségének színvonalát, de végső elemzésben középiskolai oktatásunk színvonalát is.” (Fináczy, 1922, idézi Simon, 1959, 363. o.). A gyakorlati képzés a budapesti gyakorló főgimnáziumtól 
eltekintve teljesen szervezetlen. ${ }^{13}$ A vezetőtanárok sem minden esetben alkalmasak tisztségük betöltésére (Fináczy, 1922, idézi Simon, 1959, 366-367. o.).

A korabeli középiskolai tanárképzés részletekbe menő bírálata után koncepcionális javaslatokat is olvashatunk Fináczy Ernö elnöki megnyitó előadásában. Ezek szerint törvényben kell kötelezővé tenni a tanárjelölteknek a tanárképző intézetbe való belépését. ${ }^{14} \mathrm{~A}$ tanárképzést az egyetemnek a tervszerüen összeállított szaktudományos képzéssel, a pedagógia egyetemi tanárának általános pedagógiai, neveléstörténeti és gyermeklélektani stúdiumokkal, a középiskolai tanárképző intézetnek pedig a középiskolák tanulmányi rendjét, valamint az egyes tantárgyak oktatásának „speciális módszertanát” taglaló előadásokkal kell segítenie (Fináczy, 1922, idézi Simon, 1959, 366-367. o.).

Fináczy javaslatait a budapesti egyetem tanárképző intézetének tanácsa is támogatta. A tanácstag professzort egyben felkérték a tanárképzésre vonatkozó törvényjavaslat szövegezésének elkészítésére. (A másik törvényjavaslat a középiskolai tanárok képesítésével, a tanárvizsgáló bizottságok müködésével foglalkozik. Ennek megszövegezése a Budapesti Középiskolai Tanárvizsgáló Bizottság elnökének, Szinnyei Józsefnek a nevéhez füződik.)

A Nemzetgyülés elé beterjesztett törvényjavaslat lényegét tekintve a Fináczyféle koncepción alapult. A vita nyitányaként Klebelsberg Kuno egy nagy ívü expozéban fogalmazta meg a tanárképzési reform legfőbb elemeit. A törvényjavaslat szövegét a vita után egyetlen érdemi kiegészítéssel fogadták el. Erdélyi Aladár módosító javaslata alapján kerül be az a kitétel, miszerint „a középiskolai elméleti tanárképzés elsősorban a tudományegyetemek bölcsészeti karának feladata, mely a vallás- és közoktatásügyi minister felügyelete alatt tartozik gondoskodni arról, hogy a bölcsészhallgató négyévi egyetemi tanfolyamának tartama alatt szaktudományának minden ágazatával kellős sorrendben megismerkedhessék.”. (Idézi: Ladányi, 2008, 57-58. o.) Ez a kiegészítés - amelyet a beterjesztő miniszter teljes mértékben támogatott - expressis verbis megfogalmazza a bölcsészkarok ${ }^{15}$ feladatát

\footnotetext{
${ }^{13}$ A négy éves egyetemi és tanárképző intézeti tanulmányokat követő „próbaévet” nem volt kötelező a budapesti gyakorló gimnáziumban elvégezniük a jelölteknek. (Befogadóképességnek korlátai miatt erre nem is volt lehetőség.) A szegedi egyetemen müködő tanárképző intézet pedig ekkor még nem rendelkezett gyakorló középiskolával, mivel az 1917-ben Kolozsvárott létesített gyakorlóiskola székhelyén maradt. Később, az 1922/33-as tanévtől kezdve a szegedi Baross Gábor Ảllami Föreálgimnázium hivatalosan is a gyakorlati tanítások színhelye lett, de gyakorló gimnázium rangot az 1941/42. tanévtől kapott. A nőhallgatók gyakorlatai a Szent Erzsébet Leánygimnáziumban folytak. Pécsett 1926-ban, Debrecenben 1936-ban alakult meg a gyakorlógimnázium.

${ }^{14}$ Az érvényben levő középiskolai törvény (1883. évi XXX. t. c.) a tanárjelöltek számára nem tette kötelezővé a tanárképző intézeti tagságot. Gyakorlati képzés gyanánt a négy év egyetemi tanulmány után legalább egy évig középiskolában kellett tanítania a tanárjelöltnek, amelyet magánházaknál folytatott nevelöi gyakorlattal is helyettesíteni lehetett.

${ }^{15}$ A mai olvasó számára meglepő lehet az, hogy a törvény csak a bölcsészettudományi karokat említi a tanárképzés szaktudományos részének gazdájaként. Ennek oka az, hogy az 1949-ig csak a Kolozsvárról Szegedre telepített egyetemen müködött matematikai és természettudományi kar.
} 
és felelősségét a tanárképzés szaktudományos alapját jelentő egyetemi előadások és kollégiumok tartalmának és sorrendjének tervszerủ átszervezése terén.

A középiskolai tanárok képzéséről és képesítéséről szóló 1924. évi XXVII. törvény egyedülálló a maga nemében. A magyar felsőoktatás történetében sem azt megelőzően, sem azóta nem került sor e képzési terület önálló törvény keretei között történő szabályozására.

Az új törvénnyel útjára indított tanárképzési reform legfontosabb elemei a következők:

1. Mind a négy magyarországi tudományegyetem (budapesti, szegedi, debreceni, pécsi) mellett egy-egy középiskolai tanárképzö intézetet szervezett (illetve a budapesti és a szegedi mellett újjászervezte a meglévőket).

2. A tanárképző intézet a vallás- és közoktatásügyi miniszter fennhatósága alá tartozott. Élén az elnök és a tanárképző intézeti tanári testületből szervezett igazgatótanács állt.

3. Az intézet tanári testülete az egyetem azon nyilvános rendes és rendkívüli tanáraiból állt, akik előadások és gyakorlatok tartására vállalkoztak. Ez a kör kiegészülhetett a miniszter által felkért egyetemi (múegyetemi) magántanárokkal föiskolai és középiskolai tanárokkal.

4. A középiskolai tanárságra készülőknek számára a szabályszerü egyetemi (müegyetemi) tanulmányaikkal párhuzamosan kötelezöen elöírta a négy évig tartó tanárképző intézeti tagságot. A tanárjelölteknek igazolniuk kellett, hogy az egyetemi (mủegyetemi) és tanárképző intézeti előadásokon és gyakorlatokon eredményesen részt vettek.

5. A fent jelzett tanulmányok elvégzése után legalább még egy évig valamely nyilvános középiskolában, ,elsősorban a tanárképző intézettel kapcsolatos gyakorlati középiskolában” tanitási gyakorlaton kellett részt venniük. ${ }^{16} \mathrm{~A}$ törvény ezzel párhuzamosan elöírta a tanárképző intézetek székhelyén gyakorló középiskolák felállítását.

6. A középiskolai tanárok képesítő vizsgáját továbbra is a tudományegyetemek székhelyén müködő állami vizsgálóbizottságok előtt kellett letenni. A törvény előírása szerint a szóbeli és írásbeli részből álló tanárképesítő vizsga témakörei - egyebek mellett - a szaktárgyak oktatásmódszertanára is kiterjednek.

A törvény végrehajtásának első mozzanataként 1925 nyarán egyetemközi bizottság alakult, amely megtárgyalta és elfogadta a budapesti tanárképző intézet Fináczy Ernö által kidolgozott új szervezeti szabályzatát. Ezt tekintették alapnak a szegedi, valamint az újonnan szervezett debreceni és pécsi tanárképző intézetek statútumainak

\footnotetext{
${ }^{16}$ A kötelező tanítási gyakorlat definiálása az 1883. évi XXX. törvényt írta felül, amely még megengedte a legalább egy éves középiskolai tanítási gyakorlat helyett a magánnevelői, magántanítói gyakorlat igazolását is.
} 
elkészítésekor is (Ladányi, 2008, 59. o.). Ezek a szabályzatok a képzés szervezésére vonatkozó részletesebb útmutatásukkal jelentős előrelépést jelentettek a reformelképzelések végrehajtása felé, de megalkotásuk során már bizonyos „szerepkonfliktusokra" utaló vélemények is napvilágot láttak.

Szegeden például annak ellenére, hogy ott már müködött tanárképző intézet, a bölcsészet-, nyelv- és történettudományi kar professzorait kérte fel a kultuszminiszter az új szabályzat elkészítésére. A bölcsészkar 1925. június 17-i ülésén az ott megjelentek (akik között többen nyilvánvalóan a tanárképző intézet tanárai is voltak) aggodalmuknak adtak hangot ezzel kapcsolatban. Attól tartottak, hogy az egyetem és a tanárképző intézet addigi elvi különállása fokozatosan veszendőbe mehet.

De Szeged helyzete más szempontból is eltért a másik két vidéki egyetemtől. A kultuszminiszter ugyanis elvárta, hogy itt a bölcsészkar a matematikai és természettudományi karral is egyeztetessen az új szabályzat tartalmát illetően, mivel Szegeden - egyedül az országban - e két karnak közösen kellett gondoskodnia a tanárképzés szaktudományos tartalmairól. (Ez az egyeztetés a karok együttes ülésén meg is történt.)

A szegedi szabályzat részletezőbben írja le a megújult tanárképzési rendszer egyes elemeit. Eszerint a szegedi egyetemen és a mellette szervezett tanárképző intézetben a következő összetevők szolgálják a tanárképzés célját: 1. A tanári pályára megállapított egyetemi előadások és gyakorlatok, 2. a tanárképző intézet kebelében a tanári pályára készülők számára tartott előadások és gyakorlatok, 3. a tanárképző intézet gyakorló gimnáziuma, ennek felállításáig az e célra kijelölendő helybeli középiskolák.

Ez a szabályzat több olyan elemet is tartalmaz, amelyek egységes rendszerré szerveződve megteremtették a hatékonyabb képzés kereteit. A 10. § például előírja, hogy a tanárképző intézet igazgatótanácsának tagjai kötelesek a tanári pályára készülö hallgatókat „szakszerü tanácsokkal ellátni” és „tanulmányaikat ellenőrizni”. A tanácstagok mindemellett megjelennek a gyakorló gimnázium óráin, és ott „megfigyelik az oktatás menetét és a tanárjelöltek szakszerü kiképzését”. Tapasztalataikat az igazgatótanács ülésén is megbeszélik.

Az egyetemi oktatási szabadságnak az eredményes tanárképzés érdekében történő viszonylagos korlátozását jelentette az, hogy a szabályzat leírta: a bölcsészettudományi és a természettudományi karoknak közösen kell gondoskodniuk arról, hogy az egyetemen évenként tartsanak olyan bevezetö elöadásokat, amelyek „az egyetemre lépő $\mathrm{s}$ a tanári pályára készülő hallgatókat kellően tájékoztatják választott szaktanulmányaik feladatairól." A statútum következő előírása az évtizedekig tartó tanárképzési vita végére pontot tett - legalábbis az elvek szintjén: „Az egyetemi, illetőleg tanárképző intézeti előadások során a középiskolai tanárképzés szempontjából fontos szaktudományok minden fontosabb ága oly terjedelemben és irányban tárgyaltassék, hogy a tanárjelöltek tudományszakjuk alapelveit, módszereit és föbb tanait az egyetemi tanfolyam alatt rendszeres összefüggésben megis- 
merhessék és elsajátíthassák.” Kötelezővé teszi továbbá, hogy „a Tanárképző Intézet kebelében oly elöadások is tartassanak, amelyekből a tanárjelöltek egyetemi tanulmányaik utolsó, negyedik évében szaktárgyaik módszeres kezelésére vonatkozó tájékoztatást nyerhessenek.” (A Szegedi Magyar Királyi Középiskolai Tanárképző Intézet Szervezeti Szabályzata, 1925.) Látható, ahogyan ez a szabályzat tartalmukat tekintve célszerübbé, struktúrájukat tekintve pedig szervezettebbé kívánta tenni a tanárképzést szolgáló stúdiumokat. A „kínálat” bővítése mellett az új szabályzat elvárásokat fogalmazott meg a hallgatókkal szemben is. A „leckerendben” elöírta a tanári pályára készülők számára azokat az egyetemi és tanárképző intézeti előadásokat és gyakorlatokat, amelyeket a következő félévben hallgatni voltak kötelesek, és amelyek ,szorgalmas és eredményes látogatását igazolni tartoztak.”

A reform-szabályzat a következő évtizedekre olyan kereteket szabott ki szegedi középiskolai tanárképzés számára, amely egyes területeken kézzelfogható eredményeket hozott. Példája ennek az 1940/41. tanévröl fennmaradt jegyzék, amely a középiskolai tanárjelölt hallgatók számára kötelező előadásokat sorolja fel. Illusztrációképpen néhány cím azok közül, amelyek a középiskolai oktatás szempontjainak érvényre jutását igazolják: Mester János: „A gyermek lélektana”; Firbás Oszkár: „Gyakorlóévi theoretikum”; Sík Sándor: „A magyar irodalom az iskolában”; Fröhlich Pál: „Bevezetés az előadási kísérletezésbe”; Széll Kálmán: „Gyakorlatok és kiegészítések a mechanikához”; Greguss Pál: „A középiskolai növénytani anyag módszeres feldolgozása.” (Középiskolai tanárképzőintézeti előadások, 1940/41.)

A következö két évtizedben az ország mind a négy tudományegyetemén, illetve a mellettük müködő tanárképző intézetekben az ehhez hasonló reform-szabályzatok szabták meg a képzés kereteit. Változást csak az 1948/49. tanévben bevezetett reform hozott, amely megszüntette a tanárképzö intézeteket, és a középiskolai tanárképzést a bölcsészettudományi és természettudományi karok feladatává tette. Ennek az újabb tanárképzési reformnak a részletei és a tanárképző intézet nélküli évtizedek már nem képezik jelen tanulmányunk tárgyát.

Áttekintve a magyarországi középiskolai tanárképzés történetének ezt a több mint ötven esztendős szakaszát, a középiskolai tanárképző intézet szerepét a következőkben összegezhetjük:

1. A magyarországi középiskolai tanárképzés intézményesülési folyamatával párhuzamosan zajlott a képzésben részt vevő szereplők diskurzusa a képzés tartalmairól és az azt szolgáló szervezeti formákról. Az évtizedekig tartó folyamatos vitában az egyik markáns paradigmát az egyetemi autonómiából fakadó tanítási szabadságra hivatkozó professzorok képviselték. Az e felfogással vitatkozó elméleti és gyakorló pedagógusok a bölcsészkari képzés öncélú, tudósképző jellegét kritizálva a középiskolai tanári pálya szempontjait kívánták érvényesíteni a képzésben. (Szélsőséges állás- 
pontként szólaltak meg olykor azok a hangok, amelyek a tanárképzést az egyetemröl teljesen el kívánták választani.)

2. Az Eötvös József által 1870-ben megalkotott középiskolai tanárképzö intézet célja az egyetemi autonómia viszonylagos korlátozása volt a középiskola szempontjainak határozott megjelenítésével. Ezt szolgálta az intézet fennhatósága alá tartozó budapesti gyakorló középiskola is, amely az új szakmódszertani eljárások kidolgozásának és alkalmazásának „laboratóriuma" lett.

3. Az évtizedek során világossá vált, hogy a középiskolai tanárképző intézet nem rendelkezik kellő mérvü érdekérvényesítő erővel ahhoz, hogy az autonóm egyetemi képzést számottevően befolyásolja. Döntő fordulatot hozott e téren az 1924. évi XXVII. törvény, amely az új szabályzatokkal együtt már kellő nyomatékot biztosított a tanárképző intézetek véleményének az egyetemi diskurzusokban. Így teremtődött meg a garancia arra, hogy a tanárképzés egyes összetevői (szaktudomány, szakmódszertan, pedagógia, lélektan, gyakorlati képzés) többé ne csak mozaikszerü elemek rendezetlen halmazaként jelenjenek meg egymás mellett. A tanárképző intézet hatására az egyetemi karokon is kezdetét vette egy tananyagszervezö folyamat, amelyben már a középiskola gyakorlatias szempontjai is egyre fontosabb szerephez jutottak.

Mindezek alapján megállapítható, hogy az Eötvös József által megteremtett tanárképzö intézet a húszas évektől a negyvenes évek végéig töltötte be adekvát módon azt a szerepet, amelyre az adott kor felsőoktatási struktúrája lehetőséget teremtett. Tehette ezt azért, mert egy - azóta is egyedülálló - tanárképzési törvény erős legitimációjával és az arra épülő szabályzatokban lefektetett egyértelmü jogosítványokkal rendelkezett. Megítélésünk szerint ez az a mozzanat, ami a tanárképző központok létesítése során ma is megszívlelendő lehet...

\section{Irodalom}

2005. évi CXXXIX. törvény a felsőoktatásról. URL:

http://www.math.u-szeged.hu/http://www.math.u-szeged.hu/phd/szabalyzat/ftv2011.pdf; phd/szabalyzat/ftv2011.pdf

2011. évi CCIV. törvény a nemzeti felsőoktatásról. URL: http://jogszabalykereso.mhk.hu/cgi_bin/njt_doc.cgi?docid=143567.581269

A nevelés-oktatástani szakosztály szervezeti szabályzata. In: Kármán Mór (1895): A tanárképzés és az egyetemi oktatás. Paedagogiai tanulmány. Eggenberger, Budapest, Függelék, 60-62.

A pesti magy. kir. tudomány egyetem bölcsészeti kara mellett középtanodai tanárjelöltek számára felállított állami tanárképezdének szabályzata. Életbelépett az 1870/1. tanévvel. In: Kármán Mór (1895): A tanárképzés és az egyetemi oktatás. Paedagogiai tanulmány. Eggenberger, Budapest, Függelék, 50-60. 
A Szegedi Magyar Királyi Középiskolai Tanárképző Intézet Szervezeti Szabályzata, 1925. Magyar Országos Levéltár, K 6361925.

A tanárképezde újjáalakítása. In: Kármán Mór (1895): A tanárképzés és az egyetemi oktatás. Paedagogiai tanulmány. Eggenberger, Budapest, Függelék, 62-64.

Felkai László (1983): Neveléstörténeti dolgozatok a dualizmus korából. Tankönyvkiadó, Budapest.

Fináczy Ernő (1922): Elnöki megnyitó a Magyar Pedagógiai Társaság 1922. évi február 18-án tartott XXX. közgyülésén. Magyar Paedagogia, 5. sz. 65-72. In: Simon Gyula (1959, szerk.): Neveléspolitikai dokumentumok az ellenforradalmi rendszer idöszakából (1919-1931). Tankönyvkiadó, Budapest, 360-370.

Kármán Mór (1875): A tanárképzés reformja. Magyar Tanügy. In: Kármán Mór (1895): A tanárképzés és az egyetemi oktatás. Paedagogiai tanulmány. Eggenberger, Budapest, Függelék, 2-6.

Kármán Mór (1895): A tanárképzés és az egyetemi oktatás. Paedagogiai tanulmány. Eggenberger, Budapest.

Kerékgyártó Árpád (1879): A m. kir. Egyetem bölcsészeti karának felterjesztése a középiskolai tanárképzés tárgyában. Magyar Tanügy. In: Kármán Mór (1895): A tanárképzés és az egyetemi oktatás. Paedagogiai tanulmány. Eggenberger, Budapest. Függelék. 20-30.

Kiss Istvánné (1991): Szemelvények a budapesti egyetemi tanárképzö intézet gyakorló gimnáziumának jegyzőkönyveiből. A magyar neveléstörténet forrásai VII. Országos Pedagógiai Könyvtár és Múzeum, Budapest.

Középiskolai tanárképző intézeti előadások. Szeged, 1940/41. Gépiratos dokumentum. A szegedi egyetem iratai, Csongrád Megyei Levéltár, Szeged.

Ladányi Andor (2008): A középiskolai tanárképzés története. Új Mandátum Könyvkiadó, Budapest.

Mészáros István (1980): Az ELTE Bölcsészkar Neveléstudományi Tanszékének története 1814-1900 között. Magyar Pedagógia, 1. sz. 38-57.

Németh András (2012): Magyar pedagógusképzés és pedagógus szakmai tudásformák I. 1775-1945. ELTE Eötvös Kiadó, Budapest.

Pukánszky Béla (1989): A középiskolai tanárképzés 1924-es reformja Magyarországon. Pedagógiai Szemle, 11. sz. 1045-1055.

Schneller István (1900): Paedagogiai dolgozatok. Első kötet. Hornyánszky ny., Budapest.

Schneller István (1910): Paedagogiai dolgozatok. Harmadik kötet. Hornyánszky ny., Budapest.

Simon Gyula (1959, szerk.): Neveléspolitikai dokumentumok az ellenforradalmi rendszer idöszakából (1919-1931). Tankönyvkiadó, Budapest. 